GENDER STUDIES 20(1)/2021

sciendo

10.2478/genst-2022-0005

\title{
NAN KING'S ORIENTATION IN SARAH WATERS'S TIPPING THE VELVET: A JOURNEY OF GENDER AND SEXUAL SELF-DISCOVERY FOLLOWING “THE SLANTWISE DIRECTION OF QUEER DESIRE"
}

\author{
ELSA ADÁN HERNÁNDEZ \\ University of Zaragoza \\ elsa.adan.hernandez@gmail.com
}

\begin{abstract}
In Tipping the Velvet (1998), Sarah Waters explores the notion of "gender performativity" as studied by Judith Butler (1990, 1993). Its protagonist, Nancy Astley, becomes aware of her sexuality and comes up with doubts about her gender as responding to the stable label society has put on her. This naïve girl moves from performing gender on stage to cross-dressing off-stage amid the crowds of London, not following, as Sarah Ahmed (2006) puts it, "the straight line" (p. 70). The aim of this paper is to explain how this straightness - both in terms of direction and heterosexuality - is the term Nancy, later on renamed Nan King, does not feel comfortable with. Throughout the novel, Nan's discovery of a whole world of sexual and identity possibilities leads her to look for her own orientation, as her position in relation to the rest of "objects" around her is a queer one.
\end{abstract}

Keywords: straightness, gender performance, identity, Sarah Waters.

\section{Introduction}

In the introduction of her monograph The Victorian Woman Question in Contemporary Feminist Fiction (2005), Jeanette King questions: "Why, in the last decades of the twentieth century, should so many women novelists have looked back a hundred years for the subjects of their fiction? [...] What, in particular, is the interest of Victorian constructions of gender and sexuality for modern feminists?” (p. 1). In the case of Sarah Waters, her main interest is clear: she wants to rewrite certain parts of Victorian history from the margins of patriarchal society in order to provide her own late twentieth-century outlook on it. What is more relevant, in doing so, she gives voice to all those characters who are usually silenced in History, specifically focusing on the buried and erased past of lesbian and queer women. As Michaela Weiss (2012) puts it, "returning to history, Waters is not only revitalizing the genre of queer romance but also 
re-creating and recovering a context and a line which have been doomed to be invisible" ( $\mathrm{p}$. 51). Such is the case of the opera prima of this British author, Tipping the Velvet, published in the year 1998. Waters skilfully compels readers to go beyond her fictional world, described by Steel (1999) as "sexy, irrepressible romp through working-class Edwardian music hall” (para. 1) and investigate further to uncover some thorny issues that may trigger numerous questions about our behaviour and the understanding of the world that surrounds us. This novel was born as a result of Waters's research work during her postgraduate studies, as it was created to imaginatively fill in those gaps in literary history left by the omission of homosexual writing she discovered during her research years. Hence, it is no coincidence that the attentive reader will be able to recognise the presence and relevance of varied queer or sexual politics theories, as Waters makes conscious use of them in order to trigger new ideas or question wellestablished notions within our cultural parameters. As Silvia Antosa (2015) explains, "the confrontation with the Victorian past thus becomes a transtextual exploration that conceives and confronts the nineteenth century as the cultural matrix of present-day culture" (p. 32).

Tipping the Velvet, set in England in the 1890s, tells the story of Nancy Astley, a provincial oyster girl born in Whitstable, a seaside town with straight [emphasis added] and clear ideas (Waters, 1998, pp. 4-5). She is expected to make a living as an oyster girl in the family business, get married with a kind man and live a contented life. However, during one of her visits to the theatre, she meets the male impersonator Kitty Butler and, after falling in love with her, decides to leave her home town behind and follows her to London, thus initiating her quest for maturation. Once in London, as we shall see in this article, Nancy will start to realise that there is a whole new world of sexual possibilities that opens up a new perspective on her identity. Drawing primarily on Judith Butler's theory of performativity, every stage in Nancy's maturation process will be reflected in all senses possible, from the most visible and external, to the most significant and deeply repressed. However, the story does not stop here, as a more complex understanding on the notion of gender and the possibilities of queering it can also be read in the course of her maturation process, proving right that what Butler (1990) addressed as "gender trouble" is not only a contemporary issue, but also one that could be found in more ancient contexts. Nan's received heteropatriarchal ideas about straightness will undergo constant change alongside what can be described as a process of "queering" and "being oriented" as defined by Sarah Ahmed in Queer Phenomenology (2006); that is, the process of situating ourselves in the world according to the way in which our bodies understand gender and sexuality by extending into space (p. 5) and how we are oriented in relation to the space we inhabit (p. 8). Then, in this article, special attention is placed on the notion of gender and the 


\section{GENDER STUDIES 20(1)/2021}

way in which the protagonist dismantles gender constructions that hampered non-normative people in the past, and worryingly, still hamper us in our contemporary world. Even today, gender and sexual politics seem to be, on many occasions, at the focal centre of public perception, and remain more alive than ever. Drawing on these notions, I will try to prove that Waters's rewriting of the Victorian topos of the female-to-male music-hall performer involves a transformation of the protagonist both on and, especially, off stage, and that every step of the way leads her to question certain social assumptions about gender and sexuality both in the Victorian period and nowadays.

\section{The limits of gender and Judith Butler's performativity theory}

As a point of departure, when analysing Tipping the Velvet, one of the most recurrent topics delved into is Waters's conceptualization of gender and its reflection in Nancy's performances from the perspective of Butler's theory of performativity. This theory was originally presented in Gender Trouble (1990) and then reshaped and clarified in subsequent works. As Helen Davies (2012) makes clear,

\footnotetext{
Butler's theories have had an enormous cross-disciplinary impact upon gender studies and her work has already received considerable attention in the field of neo-Victorianism, particularly in relation to [the] theme of cross-dressing/drag performance. In this respect the novels of Sarah Waters, specifically Tipping the Velvet's world of male impersonation, have emerged as particularly ripe for Butlerian readings, foreshadowed by the quotation on the cover of the 1999 paperback edition of Tipping the Velvet which reads 'Imagine Jeanette Winterson on a good day, collaborating with Judith Butler to pen a Sapphic Moll Flanders.' (p. 9)
}

First of all, it is important to bear in mind that, as Weiss (2012) remarks, in the Victorian period "cross-dressing was not an uncommon practice and as such has become a frequent motif in contemporary post-Victorian fiction, where it is used as a gender blurring tool" (p. 53). Therefore, the fact that the novel brings into action this theoretical perspective does not come as a surprise. The whole novel revolves around Nancy's transvestite performances, both on and especially off-stage. As the connection seems straightforward, many different scholars such as Cheryl A. Wilson (2006), Claire O'Callaghan (2017), Helen Davies (2012), or Lin Elinor Pettersson (2014), among others, have all explored this issue in several book chapters and scholarly papers, most of them agreeing on the usefulness of Butler's theory to explore the 
contractedness of gender in the novel. ${ }^{1}$ However, in Gender and Ventriloquism in Victorian and Neo-Victorian Fiction: Passionate Puppets (2012), Davies shows a more critical perspective on the use of performativity theory, as well as a judgemental reading of Butler's main ideas. As is suggested by the title, in her book, Davies analyses certain neo-Victorian novels from the perspective of ventriloquism, a metaphor that, as she acknowledges, is primarily based on Butler's ideas on performativity (p. 20). ${ }^{2}$ However, she shows certain objections towards the overuse of Butler's theory when reading neo-Victorian samples, as "the dominance of Butlerian understandings of gender performativity in neo-Victorian fiction runs the risk of muting Victorian voices all together" (p. 11). What is more, she does an against-thegrain analysis of Butler's Gender Trouble, highlighting some inconsistencies in her theorisation. Her main point is that Butler "does have a tendency to slide between the linguistic connotations of 'performative' and the theatrical metaphor of 'performance' without accounting sufficiently for the tension between the terms" (Davies, 2012, p. 25). Davies then puts forward another theoretical problem: if Butler asserts that the constructedness of gender is inevitably linked to social and cultural factors, how will the subject manage to appropriate a concrete gender and use it to subvert the existing norms within the pre-existing regime? (p. 26). For all this, however, Davies makes clear that, in neo-Victorian literature, "there is a tendency to perceive 'gender as performance' as having unequivocally subversive and/or liberatory implication for neo-Victorian texts which engage with the construction of gender roles" (p. 10).

After showing the variety of critical perceptions on this matter, I will now highlight the aspects of Butler's ideas on performativity that I consider most relevant for the analysis of Nan's character and the interpretation of her transvestite performances from a twenty-first century perspective. While it is clear that there are different visions on Butler's works and theories, it is undeniable that she changed the way we perceive, understand and approach topics such as sex and sexuality, language, and gender. As is stated in the Introduction to The Judith Butler Reader (2002), edited by Sarah Salih and Butler herself,

\footnotetext{
${ }^{1}$ For instance, Cheryl Wilson (2006), who agrees with the main ideas on performativity and applies this Butlerian framework to her reading of Tipping the Velvet, asserts that "Nan learns that gender and sexuality are social constructions that can - and sometimes must—be performed. Nan's experiences reflect Judith Butler's arguments about performativity and gender" (p. 296). Similarly, Pettersson (2014), who also takes Butler's Gender Trouble to explore the multiplicity and constructedness of both Nancy and Kitty's social performances (p. 18), believes that Nancy's theatricality and impersonation "emphasises the fluid dimension of gender" (p. 71). O'Callaghan (2017) readdresses this issue in one of her latest published books, where she highlights how Nancy "emphasizes the spectrum of gender trouble that cross-dressing instigates" (p. 25).

${ }^{2}$ Davies (2012) does not delve into the fluidity of genders and the "gender trouble" Nancy causes with her impersonations and disguises, but rather focuses on how "Butler's theory of performativity/performance can actually be elucidated by thinking ventriloquially about the tension between repetition and subversion, constraint and agency" (p. 20).
} 


\section{GENDER STUDIES 20(1)/2021}

If we were to approach someone working in the critical theoretical field with the question 'Who's Judith Butler?' their reply might contain the words 'queer theory', 'feminist theory' and 'gender studies'. Probe a little deeper, and you might hear 'gender performativity', 'parody' and 'drag', concepts and practices with which Butler has come to be widely associated. (p. 1)

Starting from Simone de Beauvoir's (1988) path-breaking contention that "[o]ne is not born, but rather becomes, a woman" (p. 295), Butler (1990) explains that what is relevant about de Beauvoir's argument is that the mere act of considering "woman" as a concept involves the existence of ideas under construction (p. 45). Further exploring de Beauvoir's theory, Butler (1992) adds: "one acquires a given set of cultural and historical significations, and so comes to embody an historical idea called 'woman.' Thus, it is one thing to be born a female, but quite another to undergo proper acculturation as a woman" (p. 254). Consequently, women can neither be given a concrete definition nor ascribed clear connotations, and the notion of woman itself cannot be easily grasped. Only by turning gender into an evolving and changing concept, can we fill in this void with different performances in varied ways. As Butler (1990) puts it: "As an ongoing discursive practice, it is open to intervention and resignification. Even when gender seems to congeal into the most reified forms, the 'congealing' is itself an insistent and insidious practice, sustained and regulated by various social means" (p. 45). Hence, the definition of gender is a complex issue that has been a matter of debate for decades and that is now more vibrant than ever. In fact, both de Beauvoir and Butler agree on the idea that gender is not something we "are", but rather something we "do". From Butler's (1990) perspective, "gender is the repeated stylization of the body, a set of repeated acts within a highly rigid regulatory frame that congeal over time to produce the appearance of substance, of a natural sort of being" (p. 45). This idea of embodying a concrete gender by means of acting out in a certain way would work as the foundational concept for her well-known performativity theory. We should also take into consideration that this first influential work was published in the 1990s, and that, consequently, concepts have and still are undergoing significant changes and continuous evolution. More significantly, in the last decade, this has become a very popular issue within feminist, LGBTQ+ members, and minority groups. Butler herself has recognised that her own thoughts have evolved since she first published Gender Trouble. As she states ten years after its original publication, in the 1999 Preface included in the third edition, "it is difficult to say what performativity is not only because my own views on what 'performativity' might mean have changed over time, most often in response to excellent criticisms, but because 
so many others have taken it up and given it their own formulations" (p. xv). ${ }^{3}$ Even so, as a point of departure, it is fundamental to bear in mind Butler's (1990) first definition of performativity: "[it] is not a singular act, but a repetition and a ritual, which achieves its effects through its naturalization in the context of a body, understood, in part, as a culturally sustained temporal duration" (p. xv). Besides, by reading Butler's works, we should consider that, for her, gender is "always and inevitably occurring, since it is impossible to exist as a social agent outside the terms of gender" (Butler and Salih, 2004, p. 47). As we shall see, Tipping the Velvet seems to reproduce in Nancy's moves every single word of this definition.

\section{Performing gender on and off stage}

Waters was perfectly aware of the existence and relevance of Judith Butler's influential performativity theory while she was writing Tipping the Velvet, and she consciously used it as the compass for her first fictional work. There is unequivocal textual evidence for this assertion. The first clear allusion to Butler's influence on the way Waters understands gender fluidity and mutability is the naming of the male impersonator, Kitty Butler. As several critics have pointed out (see O’Callaghan, 2016; Serrano Bailén, 2008; Wilson, 2006), Waters clearly alludes to Judith Butler in Kitty's surname, thus pointing to the centrality of performativity theory in the novel. This is O'Callaghan's (2017) clear and precise explanation of Kitty Butler's complete name: "[it] combines masculine and feminine sensibilities: Kitty is a child-like, pet name, while 'Butler' is arguably both a nod towards Judith Butler and alludes to the traditional role of male servants while also referring to Lady Eleanor Butler, one half of the famous couple, the Ladies of Llangollen" (p. 27). ${ }^{4}$ In addition to these, there is another important Victorian figure that also

\footnotetext{
${ }^{3}$ In Bodies that Matter (1993), Butler answers many of the critics' questions that arose after the publication of her first book, and she expands on some incomplete queries. Later on, in Undoing Gender (2004), Butler acknowledges that she wrote Gender Trouble from a very different standpoint to the one in which she was when rethinking and rewriting the same topic. As she makes clear, she did not have an established position within the academia and her main two aims while writing it were, firstly, "to expose what I look to be pervasive heterosexism in feminist theory" and secondly, to "try to image a world in which those who live at some distance from gender norms, who live in the confusion of gender norms, might still understand themselves not only as living liveable lives, but as deserving a certain kind of recognition" (Butler, 2004, p. 207). Butler also recognises that she wanted to "disturb - fundamentally - the way in which feminist and social theory think gender, and to find it exciting, to understand something of the desire that gender trouble is, the desire it solicits, the desire it conveys" (p. 207).

${ }^{4}$ The Ladies of Llangollen were very well-known within literary circles, as different writers of the time wrote about their story. These two Irish girls, who lived at the end of the eighteenth and beginning of the nineteenth centuries, grew up being close friends. They shared their outlook on life and living together was, as it were, a matter of destiny. They escaped to the bucolic mountains of Llangollen, where they lived up to their last days. Thus, these two women are usually taken as an example of close female friendship, although for a time they were considered to be closeted lesbians. In fact, in some records of the times, we can find that they are addressed, for example, as "eccentrics". (Mayer \& Townshend, 1869, p. 12).
} 
deserves to be mentioned: Josephine Butler (1828-1906). She was the first woman who dared to break with the established rules of the existing heteropatriarchal world. She was highly interested in women's education, being the first woman who ever entered the Bodleian library in Oxford, and who publicly addressed the taboo topic of prostitution, fighting for the defence of the women immersed in that world. She was "the woman who was brave enough to defend that unmentionable class of the Victorian person, the prostitute" (Wilson, 2006, p. 165).

As already anticipated by Kitty Butler's name, Judith Butler's words are mimed throughout the novel, both while Kitty and Nan perform transvestite roles on stage and, more interestingly, when Nancy transgresses gender roles on the streets. In the first part of the novel, both characters bring Butler's words to life by cross-dressing on various occasions. After seeing Kitty on stage, Nancy reflects:

Her figure, too, was boy-like and slender - yet rounded, vaguely but unmistakably, at the bosom, the stomach and the hips, in a way no real boy's ever was [...]. But she strode like a boy, and stood like one [...] when she sang, her voice was a boy's voice - sweet and terribly true." (Waters, 1998, p. 13)

This and other comments conveying that Kitty displays what seem genuine male and female features blended in the same performance work to dismantle stereotypical gender binaries. Take, as another example, the following comment on Kitty made by Nan: "“When I see her', I said, 'it's like - I don't know what it's like. It's like I never saw anything at all before. It's like I am filling up, like a wine-glass when it's filled with wine. [...] I never saw a girl like her before. I never knew there were girls like her [emphasis added] . . '” (Waters, 1998, p. 20). Here, for the first time, Nancy realises that her narrow-minded vision on binary genders is not everything. After their first encounter, while Nancy makes clear that she is absolutely fascinated by Miss Butler, the purblind oyster girl provides a very telling comment about her: "All at once she was the gallant boy of the footlight again" (p. 33). This remark highlights the ease and rapidity with which Kitty "switches" from one gender's appearance to its binary opposite. This, together with the fact that she - and, later on, both of them - dress up every night for the show, reinforces Butler's contention on the importance of the ritualistic repetition of acts to enact the performance of gender (1990, p. Xv). Once Nancy works as Kitty's assistant, her manager, Mr Walter Bliss, suggests that they improve the performances by means of imitation: "'you must both of you go about the city and study the men!'” (Waters, 1998, p. 83; emphasis in original). When, astonished by the request, the girls ask him what he really means, Mr Bliss answers: 


\section{GENDER STUDIES 20(1)/2021}

'Scrutinise 'em! [...] Catch their characters, their little habits, their mannerisms and gaits. What are their histories? What are their secrets? Have they ambitions? Have they hopes and dreams? [...] You must know it; and you must copy them, and make your audience know it in their turn.' (p. 83; emphasis in original)

The fact that gender roles can be studied, imitated and acted out makes clear that gender is based on cultural and societal norms agreed upon by the community. As Butler (1990) questions and further asserts:

In what senses, then, is gender an act? As in other ritual social dramas, the action of gender requires a performance that is repeated. This repetition is at once a reenactment and reexperiencing of a set of meanings already socially established; and it is the mundane and ritualized form of their legitimation. (p. 191; emphasis in original)

The above-quoted passage of the novel also echoes another of Butler's main tenets, namely, that there is not a copy and an original form, but just a copy of a copy and, so, both the considered "original" and its apparent "copy" are actively performed (Butler, 1990, p. 43). Further still, the agility to switch genders is reinforced by the figure of the oyster, a symbol attached to Nancy and her birthplace from the beginning of the novel. As Nancy tells Kitty:

You might call it a real queer [emphasis added] fish - now a he, now a she, as quite takes its fancy. A regular morphodite, in fact!' [...] 'You're a bit of an oyster, then, yourself, Kitty,' [...] 'Why, I suppose I am, she said, 'Just fancy! I’ve never been likened to a fish before!' (Waters, 1998, p. 49)

This comment not only highlights gender fluidity and the apparently simple mechanisms that allow for it to happen, but also links Kitty's role as a male impersonator to Nancy's questioning of gender fixity and her upcoming evolution. In other words, although at first Kitty is the only character who enjoys this fluidity, Nancy will eventually become the perfect embodiment of the oyster's capacity to morph.

Though transvestism is a key element in this process, the repetition of different instances of clothes-switching is not the only tool Waters uses to perform it, as Nancy will also have recourse to disguise. In so doing, she provides numerous instances of "gender trouble". By claiming that gender is a social construction, something the subject ultimately does, Butler (1990) is able to state that gender and sex should not be tied together. In her own words: "When the constructed status of gender is theorized as radically independent of sex, gender itself becomes a free-floating artifice, with the consequence that man and masculine might just as 
easily signify a female body as a male one, and woman and feminine a male body as easily as a female one" (p. 9; emphasis in original). However, in her later works, Butler is ready to admit that when gender becomes absolutely disconnected from sex “"naturally' or inevitably [...] then the distinction between sex and gender comes to seem increasingly unstable" (Butler and Salih, 2004, p. 49). In fact, this admission of instability is one of Butler's main reconsidered statements from her first published work. In Undoing Gender, Butler (2004) reflects on the "slippage" between sexual difference and gender, drawing a clear distinction between sexual difference as a concept inevitably related to language and created after cultural conditions, and gender, as "a sociological concept, figured as a norm" (p. 210). In the novel, there is a notable example of this instability when Nancy dresses up as a boy to walk down the streets, later on becoming a male prostitute. Interestingly enough, after her first promenade in male clothing, she refers to it as her "first performance" (Waters, 1998, p. 195) taking place in the streets of London. She admits that she had not yet realised how good her "performance" was until the moment-when she was looking at a tobacconist's and a man approached her and said: "There is something very masculine about a tobacconist's shop - don't you think?" (p. 197; emphasis in original), before asking for a more private encounter. Although Nancy - in her male clothing is at first confused, as she does not really know what is going on, she then learns what the man means with his proposal, referring to it as an "astonishing exchange" (p. 197). However, surprisingly enough, she is not uncomfortable or worried about the possible consequences, but rather content about the fact that she is not recognised as a woman: "any stranger looking on, I thought, would think us two quite unconnected fellows, lost in our own thoughts" (p. 198). When the sexual encounter finally takes place, the man, who, Nancy admits, looks very much like Walter, her former agent, tells her: "Your mouth is such a perfect one - quite like a girl's" (p. 199). However, he seems never to guess Nancy's biological sex behind her male impersonation, even though he appreciates an effeminate trait in him. The implications here are twofold: on the one hand, the notion of gender is on the spotlight again as Nancy starts having doubts about the category she belongs to. On the other hand, Nancy makes her customers believe that she is an effeminate boy, consequently playing not only with gender, but also destabilizing sex, as her customers seem to have no doubt that what they see and who they want to have intercourse with is a man. Through Nancy's actions, the readers understand that gender and sex can sometimes be performed in non-normative ways. Here, the establishment of gender, and the sex tied to it, not only lies in the inner self, but also in the external guise, that is to say, the body acts as a reflection of it: "Always ready as a cultural sign, the body sets limits to the imaginary meanings that it occasions, but is never free of an imaginary construction" (Butler, 


\section{GENDER STUDIES 20(1)/2021}

1990, p. 96). Consequently, after this episode, Nancy's questioning of the established matrix of the heteropatriarchal world she lives in is further triggered. The more she ventures into exploring alternative possibilities, the more she realises that she does not fit within this heteronormative world.

\section{Nancy's performative actions: Undergoing a process of queering}

Besides playing with the limits of gender and sex, Nancy is involved in a process of evolution and change, both physically and, in a more relevant way, psychologically. We shall not forget that Nancy was raised in a heteronormative working-class Victorian household and, so, she will soon start feeling uncomfortable with her received heteropatriarchal ideas about straightness. Once she moves to London, her notions of the meaning of decency, correctness, and straightness will undergo constant change alongside what can be described as a process of "queering" and "orientation" as defined by Sarah Ahmed (2006) in Queer Phenomenology: "Orientations shape not only how we inhabit space, but how we apprehend this world of shared inhabitance, as well as 'who' or ' what' [emphasis added] we direct our energy and attention toward" (p. 3). The highlighted pronouns are the most relevant words in the quotation, as Nancy will not only experience her sexual awakening through her intimate acquaintance with Kitty, but she will also feel an increasing desire to walk away from the established heteronormative and straight patterns. As a result, her understanding of the concept of gender and the implicit limitations of remaining within the commonly accepted binary system will trigger in her a further and more complex process of "re-orientation" towards a new unconventional understanding of it. Therefore, it could be argued that Nancy's quest is in itself a process of "queering". Indeed, it is the new feeling of queerness after her crucial encounter with Kitty that makes Nancy set into question the patriarchal notion of straightness and triggers her own process of self-definition. Ahmed (2006) defines the concept of "orientation" as the movement of bodies towards certain objects (pp. 5-7). Consequently, being oriented means being conscious of the point in which we find ourselves in relation to the others. Drawing on Adrienne Rich's path-breaking contention that heterosexuality is the compulsory orientation in patriarchal societies (Ahmed, 2006, p. 84), Ahmed goes on to analyse the concept of "sexual orientation". She points out that, insofar as heterosexuality is considered the natural path to follow, only homosexuals "are" oriented, in the sense that they are the ones "who 'deviate' from what is neutral" (pp. 68-69). From this perspective, it can be stated that the encounter with Kitty sets off in Nancy a process of disorientation, as she does not understand her position with 
respect to her. These feelings of queerness and unbelonging are enhanced by her sister's comments. When Nan excitedly tells Alice her first impression about Kitty's performance, the physical response she gets from her makes it clear that they perceive things in a different light. Nan says: "I opened my eyes and looked at Alice - and I knew at once that I shouldn't have spoken; [...] There was a look on her face - it was not ambiguous at all now - a look of mingled shock, and nervousness, and embarrassment or shame" (Waters, 1998, p. 20). The following day, when they go back to the theatre, Nancy only wishes to see Kitty's performance again. As she admits, "I wished, too, that I might be alone when she did so [...] rather than seated in the midst of a crowd of people to whom she was nothing, and who thought my particular passion for her only queer [emphasis added], or quaint” (p. 22).

In this process of re-orientation, Nancy realises that she does not want to marry a gentle man, and starts instead harbouring romantic feelings towards Kitty. Nancy's unwillingness to follow the straight - or heterosexual - line arranged for her by her family leads her to start reorienting her body towards what Ahmed (2006) describes as "the slantwise direction of queer desire" (p. 70). Especially after moving to London, Nancy's idea of queerness undergoes a complex evolution. As Ahmed (2006) points out, "the queer orientation might not simply be directed toward the 'same sex', but would be seen as not following the straight line [emphasis added]" (p. 70). Indeed, the deeper Nancy ventures into this re-orientation process, the more she realises not only that the others had doubts about how to "label" her, but also that “[s]ometimes I was not sure myself” (Waters, 1998, p. 195). Through the very act of asking herself what category she should identify with in order to belong to a gender considered to be straight or "real", she destabilises the notion of a fixed reality (Butler, 1990, p. xxiv). ${ }^{5}$ From this moment on, a wider spectrum of possibilities opens up for her, although, from the start, she feels disoriented and lost. As Ahmed (2006) explains, the fact of “"getting lost' still takes us somewhere; and being lost is a way of inhabiting space by registering what is not familiar: being lost can in its turn become a familiar feeling" (p. 7).

Throughout the novel, Waters uses the word "queer" with the aim of raising awareness of its different meanings, emphasising its multiplicity. Indeed, its connotative richness has become a trademark in Waters's fictions. In Tipping the Velvet the word queer - or derived

\footnotetext{
5 "The body may be preoperative, transitional, or postoperative; even 'seeing' the body may not answer the question: for what are the categories through which one sees?" [...] When such categories come into question, the reality of gender is also put into crisis: it becomes unclear how to distinguish the real from the unreal. And this is the occasion in which we come to understand that what we take to be 'real,' what we invoke as the naturalized knowledge of gender, is, in fact, a changeable and revisable reality." (Butler, 1990, p. xxiv, emphasis in original)
} 
forms of it, like "queerness" - appears approximately fifty times. There are numerous examples that perfectly illustrate this broader and all-encompassing meaning of the word. For instance, after sharing the stage with Kitty in transvestite performances and falling in love with her, Nancy wonders: "How could you dress like this, before a hall of strangers, every night, and not feel queer [emphasis added]?” (Waters, 1998, p. 114). I think this sentence is particularly revealing as, besides conveying the idea that Nancy finds the situation strange or unusual, it makes her feel weird in every sense of the word, and puts strong emphasis on the recognition of homosexual love as a possible sexual orientation. Yet, at some points, its use also raises the reader's awareness of the protagonist's refusal to fit into one of the two parts of the gender binary, as can be read on many occasions, where Nancy finds different situations "queer", meaning "out of the normal" (pp. 9, 82, 118, 162, 250, 401). Its playfulness and flexibility allow Waters to use it in different contexts, usually referring to things or happenings considered to be out of the norm, but never making explicit reference to homosexual desire. However, we should bear in mind that, in the Victorian period, the word "queer" was also a derogatory euphemism meaning homosexual, a sexual orientation that was still unmentionable and thus doomed to inexistence. What is more, in relation to lesbians, this was not even considered a possibility and, as a consequence, sexual attraction between women was not given any attention. However, it did exist and Waters makes readers become aware of it by making recurrent allusions through word puns in all her works. For instance, when Nancy moves to London and has to live with Kitty and some other theatre people, she comments: "But if I were to stay with her, then it must be as she said; I must learn to swallow my queer [emphasis added] and inconvenient lusts, and call her "sister"' (Waters, 1998, p. 78). In this sentence, the double meaning of the word is explicit: Nancy feels "queer", meaning both strange and sexually attracted to Kitty, although, due to Victorian constraints, this love must be hidden and shuttered, ultimately disguised as untainted sisterly love.

Besides, in accordance with Ahmed's (2006) metaphor of the straight and slantwise lines, Waters's word plays also make it clear, on different occasions, that Nancy will not follow the straight line (p. 70), but will rather choose the slantwise - or queer - line instead. After running away from Kitty, Nancy tries to earn a living as a male prostitute by walking the streets of London dressed up as a man. It is at this point that her performances acquire a more meaningful sense, as each of them bears further connotations. On one occasion, when she decides to go into a rented room to change clothes, she makes a revealing comment about the lodger: "I think she was never quite sure if I were a girl come to her house to pull on a pair of trousers, or a boy arrived to change out his frock" (Waters, 1998, p. 195). The ambiguity of her 


\section{GENDER STUDIES 20(1)/2021}

looks points to an identitarian in-betweenness that Nancy comments on later, when she wonders whether she is a woman or a man. She realises that she has elements of both genders while, at the same time, she feels as belonging to none. Therefore, a central aspect of the novel is the process of construction of Nancy's identity as a human being in a world that seems increasingly queer for her, in both senses of the word. For example, when, after leaving Kitty, Nancy is looking for a place to stay, she comes across a sign with the following advertisement: "Lady Seeks Fe-Male Lodger" (p. 211). Her answer could not be more revealing: "There was something really appealing about the Fe-Male. I saw myself in it - in the hyphen” (p. 211). Her identification with the hyphen leaves no doubt that she thinks of herself as queer; first, due to her sexual orientation and, more significantly, due to the way in which she understands her gender, her body and, by extension, her world. As Ahmed (2006) explains, "bodies become straight by tending toward straight objects, such that they acquire their 'direction' and even their tendencies as an effect of this 'tending toward"' (p. 86). Not surprisingly, Butler's voice is echoed here once more. While struggling with the notion of gender, Butler (1990) inevitably associates it to the body, as it is through it that the performance ultimately acquires its real meaning: "the body is figured as a mere instrument or medium for which a set of cultural meanings are only externally related. But 'the body' is itself a construction, as are the myriad 'bodies' that constitute the domain of gendered subjects" (p. 12, emphasis in original).

Echoing the disorientation Nancy is undergoing during her process of sexual discovery, she finds the world surrounding her stranger than ever, begging to be understood and clarified. As Ahmed (2006) explains, "disorientation is a way of describing the feelings that gather when we lose our sense of who it is that we are. Such losses can be converted into the joy of a future that has been opened up" (p. 20). Nancy admits that, after the success of her first transvestite performance in the street, she decided that becoming a male prostitute could help her improve her situation: "Thus easily - as easily, and fatefully, as I had first begun my music-hall career thus easily did I refine my new impersonations, and become a renter” (Waters, 1998, p. 202). It is at this stage that she begins to realise that a so-called "girl" can take different forms apart from the one she had known until that moment. What struck her at first as rather odd will become more and more customary for her. As she puts it: "How had my sense of the world been changed, since then!” (p. 200). In relation to this, there is a very telling comment that must be given some attention. Although it is a long extract, it is worth quoting it in full:

I looked into the crowds that passed me by on every side. There were three hundred, four hundred, perhaps five hundred men there. How many of them were like the gentleman whose parts I had just fingered? 


\section{GENDER STUDIES 20(1)/2021}

Even as I wondered it I saw one fellow gaze my way, deliberately - and then another. Perhaps there had been many such looks since I had returned to the world as a boy; but I had never noticed them or grasped their import. Now, however, I grasped it very well - and I trembled again, as I did so, with satisfaction and spite. I had first donned trousers to avoid men's eyes; to feel myself the object of these men's gazes, however, these men who thought I was like them, like that - well, that was not to be pestered; it was to be, in some queer way, revenged. (Waters, p. 201; emphasis in original)

This passage - it is essential to keep the words in italics as in the original - makes several interesting points. First of all, it highlights one of the main ideas Butler reworks several times, namely that the final step to become gendered is made by and within society. As Butler (2004) perfectly explains,

The particular sociality that belongs to bodily life, to sexual life, and to becoming gendered (which is always, to a certain extent, becoming gendered for others) establishes a field of ethical enmeshment with others and a sense of disorientation for the first-person, that is, the perspective of the ego. As bodies, we are always for something more than, and other than ourselves. (p. 25; emphasis in original)

As I have been arguing, this disorientation mentioned by Butler is one of the main arguments developed by Ahmed (2006) in Queer Phenomenology. As she convincingly argues, no matter how oriented or disoriented we might be, consciousness is ever present and, so, it is "intentional: it is directed toward something" (p. 27). In Nancy's case, even if her experimentation with new aspects of life makes her feel out of place, it also triggers new thought-provoking ideas. Consequently, she progressively establishes a new life path, which moves further and further away from the straight line from which she departed. The fact that she admits that her male disguise was first aimed to avoid the gaze of men is also highlighted as an obvious feminist critique of heteronormativity. As Pettersson (2014) explains referring to female transvestism, "the gaze becomes feminized due to the fact that they are women under their disguise, and through the feminization of the gaze power relations become reversed" ( $\mathrm{p}$. 77). However, the definitive twist comes when Nancy realises that the male gaze still operates within the world of men, even though in a different way or with distinct implications. The most relevant fact here, as far as the main topic of this article is concerned, is the final italicised word: revenged. Nancy realises that the real aim of her cross-dressing is to take revenge on all the cultural and social impositions, both regarding gender and sex, she has been forced to endure. As Weiss (2012) explains, Nancy "rejects the standard division of gender and its stereotypes, but at the same time she conforms to them and uses them for her own ends" (p. 58). Even though 


\section{GENDER STUDIES 20(1)/2021}

Butler (2004) distinguishes the categories of men and women from the idea of sexual difference (p. 210), Waters challenges a closed minded heteropatriarchal system by proving that gender is indeed performative and can easily disrupt society by using simple artefacts such as crossdressing. Conclusively, it proves, echoing Butler's (1990) words, that "sex does not cause gender, and gender cannot be understood to reflect or express sex" (p. 152). Indeed, Nancy recognises that she is satisfied by the attention she gets from men, as she becomes aware of how easy it is to impersonate one concrete gender in the eyes of society, once more dismantling the fixation of genders and, by extension, its assumption over sex.

\section{Conclusion}

As I have tried to demonstrate, if to be "in line" is, as Sarah Ahmed (2006) explains, directing ourselves towards "marriage and reproduction" (p. 74), then Nancy is clearly creating her own curved path by orienting her body away from it. Nancy identifies with queerness as she derails from the compulsory orientation she was supposed to follow. As an example of neoVictorian fiction, Tipping the Velvet mediates between past and present concerns, as is the case with the construction of queer identities, bringing to the fore the evolution of the cultural ban on homosexuality. Analysing Nancy's process of reorientation from a contemporary perspective allows us to state that, while performing, she is not simply wearing male clothing but taking "masculinity as the main target of [her] performance and, by so doing, both reveal[ing] the constructed condition of masculinity and account[ing] for alternative forms of contemporary gender variance" (Escudero-Alías, 2009, p. 68). Indeed, Butler (1990) describes gender as "thoroughly and radically incredible" (p. 193; emphasis in original), and this is precisely what Nancy's character represents: someone who freely expresses her true being by causing gender trouble. Paradoxically, by finally accepting and embracing the fluidity and obliqueness of queerness, she becomes incredibly real.

\section{References}

Ahmed, S. (2006). Queer Phenomenology. Duke University Press.

Antosa, S. (2015). "What is it with Queers and History?" Performing History and Gender in Sarah Waters's Tipping the Velvet. Rivista di Studi Vittoriani, 40, 31-49.

Butler, J. (1993). Bodies that Matter. Routledge.

Butler, J. (1990). Gender Trouble (3rd ed.). Routledge.

Butler, J. (1992). Gendering the Body: Beauvoir's Philosophical Contribution. In A. Garry \& M. Pearsall (Eds.), Women, Knowledge, and Reality: Explorations in Feminist Philosophy (pp. 253-262). Routledge. 


\section{GENDER STUDIES 20(1)/2021}

Butler, J. (2004). Undoing Gender. Routledge.

Butler J., \& Salih S. (2004). The Judith Butler Reader. Blackwell Publishing.

De Beauvoir, S. (1988). The Second Sex. H. M. Parshley (Ed. and Trans.). Pan Books Press.

Davies, H. (2009). Gender and Ventriloquism in Victorian and Neo-Victorian Fiction: Passionate Puppets. Palgrave Macmillan.

Escudero-Alías, M. (2009). Long Live the King: A Genealogy of Performative Genders. Cambridge Scholars Publishing.

King, J. (2005). The Victorian Woman Question in Contemporary Feminist Fiction. Palgrave Macmillan.

Mayer, S., \& Townshend R. (1869). The Ladies of Llangollen. Notes and Queries, 4(79), 12-13.

O’Callaghan, C. (2016). 'Grisley 'L' Business': Re-evaluating Female Masculinity and Butch subjectivity in Tipping the Velvet and The Night Watch. In A. Jones \& C O'Callaghan (Eds.), Sarah Waters and Contemporary Feminisms. (pp. 193-214). Palgrave Macmillan.

O’Callaghan, C. (2017). Sarah Waters: Gender and Sexual Politics. Bloomsbury.

Pettersson, L. E. (2014). Gender Performance and Spatial Negotiation in the Neo-Victorian Novel. Imagraf.

Serrano Bailén, A. (2008). Historia e identidad sexual en las novelas de Sarah Waters. Universidad de Alicante.

Steel, M. (1999, May 2). Books: A journal of two very different hearts. The Independent. Retrieved from https://www.independent.co.uk/arts-entertainment/books-a-journal-of-two-very-different-hearts1091013.html [Accessed 2020, 13 March].

Waters, S. (1998). Tipping the Velvet. Virago Press.

Weiss, M. (2012). Tipping the History: Gender Performances and Costumes that Matter in Sarah Waters's Tipping the Velvet. Moravian Journal of Literature and Film, 3(2), 51-61.

Wilson, C. A. (2006). From the Drawing Room to the Stage: Performing Sexuality in Sarah Waters's Tipping the Velvet. Women's Studies, 35(3), 285-305.

Elsa ADÁN HERNÁNDEZ is a PhD candidate from Arnedo (La Rioja, Spain). She completed her degree in English Studies in 2015 at the University of Zaragoza. Then, she studied a Master of advanced studies in literature and film also at the University of Zaragoza and completed her Mater Thesis with special mention in October 2016, in which she analysed in detail Affinity (1999), one of the best-sellers by British author Sarah Waters. She is currently a PhD student at the Faculty of Philosophy and Letters in Zaragoza. Her main research interests concern British contemporary literature, where she focuses on gender, feminist and queer studies, specially exploring these issues from the perspective of the historical novel, and the consequences it may have within our contemporary cultural parameters. 